\title{
THE ROLE OF UNMANNED AERIAL VEHICLES IN THE FORMATION OF A SECURE MILITARY SUPPLY CHAIN
}

\author{
ppłk dr inż. Zdzisław Malinowski
}

War Studies University

\begin{abstract}
The research problem described in the paper originates from the lack of adequate force protection of tactical level logistic units supporting forces in battle. The author tries to prove the necessity of the application of unmanned aerial vehicles (UAV) in order to ensure security of tactical level supply chains. The new technologies may be an innovative and perspective solution for the problem of the absence of force protection structures in logistic units. The author considers the use of UAVs for observation, reconnaissance and active force protection of logistic points and logistic units supporting tactical level forces. The problem is to choose the correct UAV type and to organise the unmanned autonomous systems (UAS) defined as electromechanical systems with no human operator on board, capable of performing operations in airspace ${ }^{1}$.
\end{abstract}

Keywords: Unmanned Aerial Vehicles, Unmanned Autonomous Systems, Military Supply Chain, electro-mechanical system

\section{Introduction}

Logistics at tactical level have had a problem for years with a lack of adequate force protection of logistic subunits performing combat logistic support tasks.

1 Autonomy Levels for Unmanned Systems (ALFUS) Framework Volume I: Terminology Version 1.1 by the Federal Agencies Ad Hoc Autonomy Levels for Unmanned Systems Working Group Participants, Edited by: Hui-Min Huang National Institute of Standards and Technology, September 2004, s. 20. 
This applies to both logistic points developed by logistic subunits at various levels of command as well as formed supply convoys. Supply chains organised by logistic subunits at each tactical level are particularly exposed to the impact of the enemy. In prior solutions, the organiser of the logistic system did not organise structures to carry out the force protection of logistic points and convoys carrying supplies to troops in accordance with the delivery plan. Therefore, there is a need to fill this gap with new technologies developed in recent years and used by NATO armies, namely unmanned aerial vehicles. The problem in this case will be selection of a specific class UAV at various tactical levels. The selection will depend on many factors, which are considered in this article. Furthermore, the location of the UAV control point, the airspace control centre and selection of the right people for these tasks should all be considered. One may quote B. Sajduk who indicates that the twenty first century is the moment for creating a new paradigm of asymmetric soldier, which includes, among other things, operators of drones².

\section{The characteristics of unmanned aerial vehicles}

An unmanned aerial vehicle (UAV) can be defined as a "driven air object", which does not lift the operator up and uses aerodynamic forces to provide a vehicle capacity $^{3}$. UAV can fly independently or be remote controlled by the operator. It is a disposable object, or it can be used repeatedly. However, if this type of technology is used in logistics, efforts should be made to acquire vehicles that will be used repeatedly, and after damage is repaired and put back into the force protection system of logistic subunits.

The term "unmanned aerial vehicle - unmanned aerial platform" is the current official terminology, which replaced the previously used term "remotely controlled vehicle".

2 B. Sajduk, Problem walki na odlegtość w perspektywie historycznej, społecznej i etycznej, [w:] Systemy dronów bojowych. Analiza problemów i odpowiedzi społeczeństwa obywatelskiego, (red.) K. Kowalczewska, J. Kowalewski, Scholar, Warszawa 2015.

3 L. Cwojdziński, Klasyfikacja oraz zasady eksploatacji bezzałogowych platform latajacych, motoszybowce.pl, (10.02.2017 r.), s. 30.

4 Ibidem. 
At the current technological development level, UAVs are remotely controlled by operators and need adequately trained personnel capable of installation, maintenance and service of a flying platform and its systems, i.e. sensors and weapons. The operator's work is dependent on the sustainment of UAV communication systems, through which they can control platforms and collect relevant information from the battlefield. It is assumed that communication systems should ensure the guidance of UAV and keep image transmission in real time, which is difficult to achieve at the current level. This is especially important because of the necessity of long-term work of UAVs in the context of the force protection of logistic points and supply convoys. Therefore, no less important than aerial platforms are sensors and communication equipment which may have a decisive influence on the overall design of the system. The use of UAVs sensors have to balance the need of high resolution and sensitivity required with the requirements of the smallest possible system, which must be adjusted to the available platform without increasing weight. In the case of imagery surveillance, UAV parameters depend on the compilation of the flight altitude with the resolution and sensitivity of used sensors.

According to the NATO classification from 2009, there are three main classes of UAVs:

1. Class I - systems of less than 150 kilograms, used to support operations at the lowest tactical level, i.e. team, platoon or company level, with a flight duration up to 6 hours.

2. Class II - systems with weight from 150 to 600 kilograms, used to support operations at higher tactical level, i.e. battalion or brigade level, with a flight duration up to 24 hours.

3. Class III - systems with weight more than 600 kilograms, with a flight duration up to 40 hours, operating at high altitude (over 3000 meters), used to support activities at operational and strategic levels.

The most important criteria of the current division are the operational range and the flight altitude. In each class, there are additional categories of UAVs that correspond to different levels of command (Table 1). 


\begin{tabular}{|l|l|l|l|l|}
\hline Class & Category & Level & Flight altitude $(\mathrm{m})$ & $\begin{array}{l}\text { Operational } \\
\text { range }(\mathrm{km})\end{array}$ \\
\hline \multirow{4}{*}{ Class I $<150 \mathrm{~kg}$} & MACRO & platoon & $<60$ & $5 \mathrm{LOS}$ \\
\cline { 2 - 5 } & MINI & company & $<305$ & $25 \mathrm{LOS}$ \\
\cline { 2 - 5 } & SMAL & $\begin{array}{l}\text { battalion/ } \\
\text { regiment }\end{array}$ & $<366$ & 50 LOS \\
\hline $\begin{array}{l}\text { Class II } \\
150-600 \mathrm{~kg}\end{array}$ & TACTICAL & brigade & $<915$ & 200 LOS \\
\hline \multirow{2}{*}{ Class III $>600 \mathrm{~kg}$} & MALE & $\begin{array}{l}\text { operational/ } \\
\text { theatre of } \\
\text { operations/ } \\
\text { division, corps }\end{array}$ & 12192 & $\begin{array}{l}\text { unlimited } \\
\text { BLOS }\end{array}$ \\
\cline { 2 - 5 } & HALE & strategic & 19812 & $\begin{array}{l}\text { unlimited } \\
\text { BLOS }\end{array}$ \\
\hline
\end{tabular}

Remarks: BLOS - Beyond Line Of Sight- out of reach of direct communication by using retransmission or satellite communications.

LOS - Line Of Sight- in direct communication between the aerial platform and the ground control station.

Source: Aktualny stan rozwoju bezzałogowych systemów autonomicznych w SZ RP, CDiSzSZ, Bydgoszcz 2015, p. 13.

\section{Table 1. Classification UAV according to NATO}

In the case of unmanned aerial vehicle custom parameters (airframe $20 \mathrm{~kg}$ and altitude over 2000 metres or an operational range more than $200 \mathrm{~km}$ ), the decisive criterion is the weight of UAV on the flight. Unmanned aerial vehicles with such parameters will be placed in Class I up to $150 \mathrm{~kg}$.

Another classification (Table 2), applied in practice, was developed by the American Publishing House IHS Jane's Defence. It is based on two principal operating parameters characterising each UAV. These include the maximum operating range and the duration of flight. Flight altitude is also used as the alternative operating parameter, which is not considered as essential due to the wide range of altitudes the tasks by various UAVs are performed ${ }^{5}$.

5 Klasyfikacje i wymagania dla bezzatogowych statków powietrznych UAV w Polsce, Redakcja Militarium, http://militarium.net/klasyfikacje-i-wymagania-dla-bezzalogowychstatkow-powietrznych-uav-w-polsce/, (05.02.2017 r.). 


\begin{tabular}{|l|l|l|l|l|}
\hline Class & Category & $\begin{array}{l}\text { Operational } \\
\text { range }\end{array}$ & $\begin{array}{l}\text { Flight } \\
\text { altitude }\end{array}$ & Duration of flight \\
\hline Micro & MICRO & up to $10 \mathrm{~km}$ & up to $250 \mathrm{~m}$ & 1 hour \\
\hline Miniature & MINI & up to $10 \mathrm{~km}$ & up to $300 \mathrm{~m}$ & $1-2$ hours \\
\hline Close Range & CR & $10-30 \mathrm{~km}$ & $3000 \mathrm{~m}$ & $3-6$ hours \\
\hline Short Range & SR & $30-70 \mathrm{~km}$ & $3000 \mathrm{~m}$ & $3-6$ hours \\
\hline Medium Range & MR & $70-200 \mathrm{~km}$ & $5000 \mathrm{~m}$ & $6-10$ hours \\
\hline $\begin{array}{l}\text { Medium Range } \\
\text { Long Endurance }\end{array}$ & MRLE & more than $500 \mathrm{~km}$ & $8000 \mathrm{~m}$ & $10-18$ hours \\
\hline $\begin{array}{l}\text { Low Altitude } \\
\text { Deep Penetration }\end{array}$ & LADP & more than $250 \mathrm{~km}$ & $9000 \mathrm{~m}$ & up to 18 hours \\
\hline $\begin{array}{l}\text { Low Altitude } \\
\text { Long Endurance }\end{array}$ & LALE & more than500 km & $3000 \mathrm{~m}$ & up to 24 hours \\
\hline $\begin{array}{l}\text { Medium Altitude } \\
\text { Long Endurance }\end{array}$ & MALE & more than500 km & $13000 \mathrm{~m}$ & more than 24 hours \\
\hline $\begin{array}{l}\text { High Altitude } \\
\text { Long Endurance }\end{array}$ & HALE & more than500 km & $20000 \mathrm{~m}$ & more than 24 hours \\
\hline
\end{tabular}

Source: Klasyfikacje i wymagania dla bezzałogowych statków powietrznych UAV w Polsce, Redakcja Militarium, http://militarium.net/klasyfikacje-i-wymagania-dla-bezzalogowych-statkowpowietrznych-uav-w-polsce/, (05.02.2017 r.).

Table 2. UAV classification according to American Publishing House IHS Jane's Defence

In the Program of Technical Modernization of the Polish Armed Forces for 20132022, in relation to the relevant classification, the essential requirements for UAV were adopted. For UAV class miniature version Viewfinder, it was determined that the start and landing should take place at the unprepared ad hoc chosen place (airplane or rotorcraft platform), the operational range to meet the requirements should be up to 30 kilometres and flight duration at least 1.5 hours. The object should be equipped with a system of observation working in visible light or infrared. Furthermore, data links, the observation head control, and the operator interface should be compliant with STANAG $4586^{6}$.

For another short range UAV version Columbine, it was determined that the start and landing should take place at the unprepared ad hoc chosen place too

6 STANAG 4586(NATO Standardization Agreement 4586) is a NATO Standard Interface of the Unmanned Control System (UCS) Unmanned Aerial Vehicle (UAV) interoperability. It defines architectures, interfaces, communication protocols, data elements and message formats. It includes data link, command and control, and human/computer interfaces. 
(airplane or rotorcraft platform), and should have collision avoidance systems, should carry a compatible identification "friend or foe" (IFF) and an observation system operating in visible light or infrared. It was assumed that the operational range would be up to 100 kilometres and the duration of flight over 6 hours. It was also determined that data links, the observation head control, the aerial platform control and the operator interface should correspond to the standardisation according to STANAG 4586.

Medium range UAVs in reconnaissance and reconnaissance-striking Griffin versions also have to be prepared to take off and land at an unprepared ad hoc chosen place (airplane or rotorcraft platform), equipped with automatic takeoff and landing system with a minimum operational range of $200 \mathrm{~km}$, using a mutual retransmission and endurance of at least 10 hours. An observation system operating in the visible or infrared was planned as combat equipment, while mandatory STANAG 4586 requirements were adopted covering: data links, the observation head control, the aerial platform control and the operator interface.

The last of the UAVs adopted in the Program of Technical Modernisation of the Polish Armed Forces for 2013-2022 was the operational class MALE in the Zephyr reconnaissance-striking version, which should meet the requirements mentioned above, with a minimum operational range of $1000 \mathrm{~km}$, using retransmission and endurance for more than 24 hours. As specific combat equipment there is: radar with synthetic aperture and the Ground Moving Target Indicator (GMTI), and an observation system operating in the visible or infrared. Other requirements should meet STANAG 4586 as in the previous construction solutions ${ }^{7}$.

Multitasking systems of unmanned platforms carrying weapons have proved effectivein attacking ground targets during asymmetric conflicts. Depending on the task, they can be configured and equipped with proper armaments. Both the reconnaissance and imagery systems' weight and weapons' weight affect the duration and range of the flight of the UAV. Reconnaissance UAVs can be equipped with armaments when an on the spot attack on a detected target is executed.

7 Klasyfikacje $i$ wymagania dla bezzatogowych statków powietrznych UAV w Polsce, Redakcja Militarium, http://militarium.net/klasyfikacje-i-wymagania-dla-bezzalogowychstatkow-powietrznych-uav-w-polsce/, (05.02.2017 r.). 
However, in these platforms, the emphasis is primarily on reconnaissance and endurance. In the case of tasks with usage of lethal ammunitions, a reconnaissance UAV carries a full load of weapons which allows the destruction of a particular target but reduces endurance.

In conclusion, UAVs moving through the air at high altitudes require appropriate sensors characterised by high resolution and sensitivity. Smaller unmanned platforms operating at lower altitudes can use sensors with lower resolution and sensitivity while remaining effective. It can also be accepted that platforms of reconnaissance and force protection subsystems are a form of guard duty, which can be carried out by UAVs. Usually, this task is performed by small or medium size systems, moving at low altitude.

What UAV should be used, therefore, to build secure supply chains in the army in times of peace, crisis and war?

\section{The selection of unmanned aerial vehicles for building secure supply chains in the army}

The selection of UAV should consider tasks and structures of executive logistics at tactical levels and combat environments in which combat logistic support will be conducted. The first tactical level is supported by the logistic company (LOGCOY) consisting of command team (COMTM), supply platoon (SUPPLT), and maintenance platoon (MAINTPLT). In the logistic company structure (Figure 1), there are no force protection elements which should be associated with logistic subunits at this level. The experience of previous missions in Iraq and Afghanistan indicate that in order to properly protect and defend logistic points and convoys, it is essential to have subunits equipped with armoured combat vehicles. However, when it is not possible due to a limited number of soldiers and costs associated with maintaining an adequate structure to provide force protection, the use of new technologies available in the civil and military markets should be taken into consideration. The UAV is such a solution. The problem at the tactical level, as well as on the others, is the selection of appropriate UAV type, how many, their place in formation, purpose, method of use and control to perform the tasks 
of force protection of convoys and logistic points developed by LOGCOY. The use of UAVs should also be considered in specific combat environments, terrain, weather, climate and time of day. Obviously, this is essential when selecting appropriate UAVs equipped with sensors and devices for collecting information from the battlefield (different environments and conditions of climate and terrain), where logistic subunits will conduct their tasks.

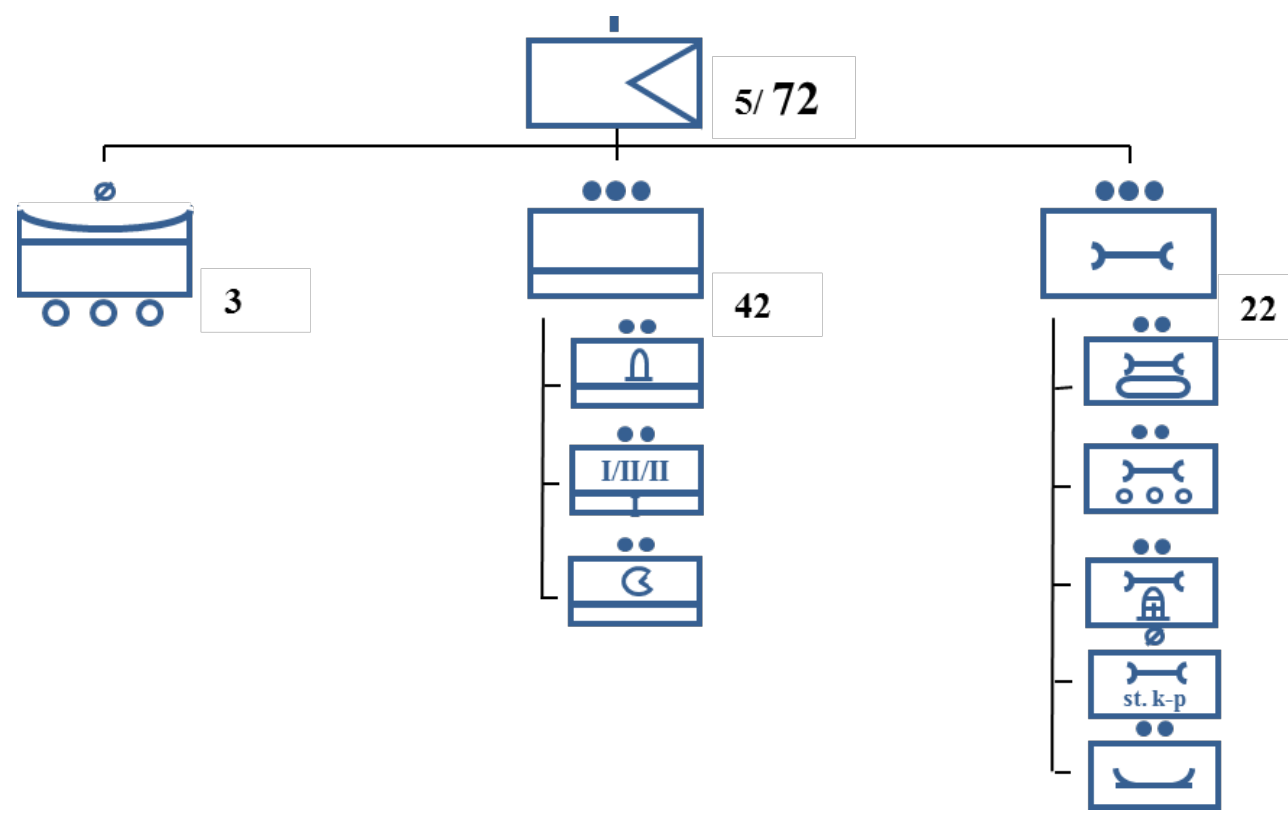

Source: Poradnik logistyczny do ćwiczeń i treningów sztabowych (Związek taktyczny, oddział, pododdziaf), M. Kaźmierczak (editor), ASzWoj, Warszawa 2016, p. 19.

Figure 1. The structure of LOGCOY of a mechanised battalion

When organising supply convoys, the number of vehicles and type of transported supplies, deadlines and route of transport to logistic release points, time of transfer cargo, and return route should be determined. These factors will also influence release points, the selection of the appropriate class of UAV and their quantity. In the case of a convoy consisting of 6-8 vehicles with ammunition and fuel, 1-2 reconnaissance UAVs and 1-2 combat UAVs with the appropriate type of weapons should be set. Obviously, there could be more combinations of factors - it depends on the environment in which they will carry out the tasks. It may be enough to use one reconnaissance UAV with basic reconnaissance equipment and 
one combat UAV. Such solutions should be checked in reconnaissance practice, taking into account personal experience and that of other NATO countries. On the other hand, the distance between the supply and reception points and the calculation of time will allow a suitable UAV to be selected, which will remain long enough in the air to perform tasks of reconnaissance and strike at objects posing a potential threat to the convoys.

Attention should also be paid to the time of unloading operations and the return to its place in the formation in accordance with the principle of utilisation of a capacity of vehicles during the return. Therefore, there is a need to add the time for loading personnel or goods which are redundant in the area of responsibility of the supplied subunit. The previous considerations result in the idea that these factors will determine the selection of the right kind of unmanned platforms.

One should not forget about medical support implemented at this level by the medical evacuation team (MEDEVACTM) consisting of 3 or 4 medical evacuation groups (MEDEVACGP) depending on the type of subunit. The exemplary structure of this team from the motorised/mechanized battalion is shown in Figure 2. It consists of four MEDEVACGP.

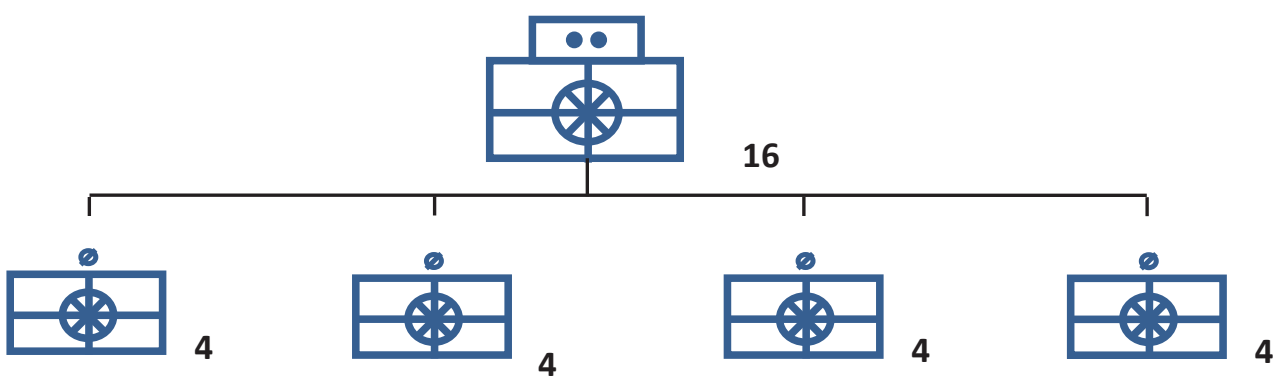

Source: Poradnik logistyczny do ćwiczeń i treningów sztabowych (Związek taktyczny, oddział, pododdziaf), M. Kaźmierczak (editor), ASzWoj, Warszawa 2016, p. 19.

Figure 2. The structure of medical evacuation team of motorised/mechanised battalion

In this case, UAVs should be used for the detection and identification of places of wounded, sick and died soldiers on the battlefield. Then the UAV with a high rate of imagery resolution of the battlefield, a long duration of flight and operational range should be obtained. UAVs should also be equipped with devices capable of examining the health parameters of injured soldiers. It can be assumed that, at 
this level, there is no need to have too many UAVs, but it is necessary to determine the appropriate class and their number.

Another tactical level is supported by a logistic battalion (LOGBN) composed of the command platoon (COMPLT), the supply company (SUPCOY), the maintenance company (MTNCOY), and medical evacuation team (Figure 3). It is a mobile supply and maintenance potential performing combat logistic support on the battlefield.

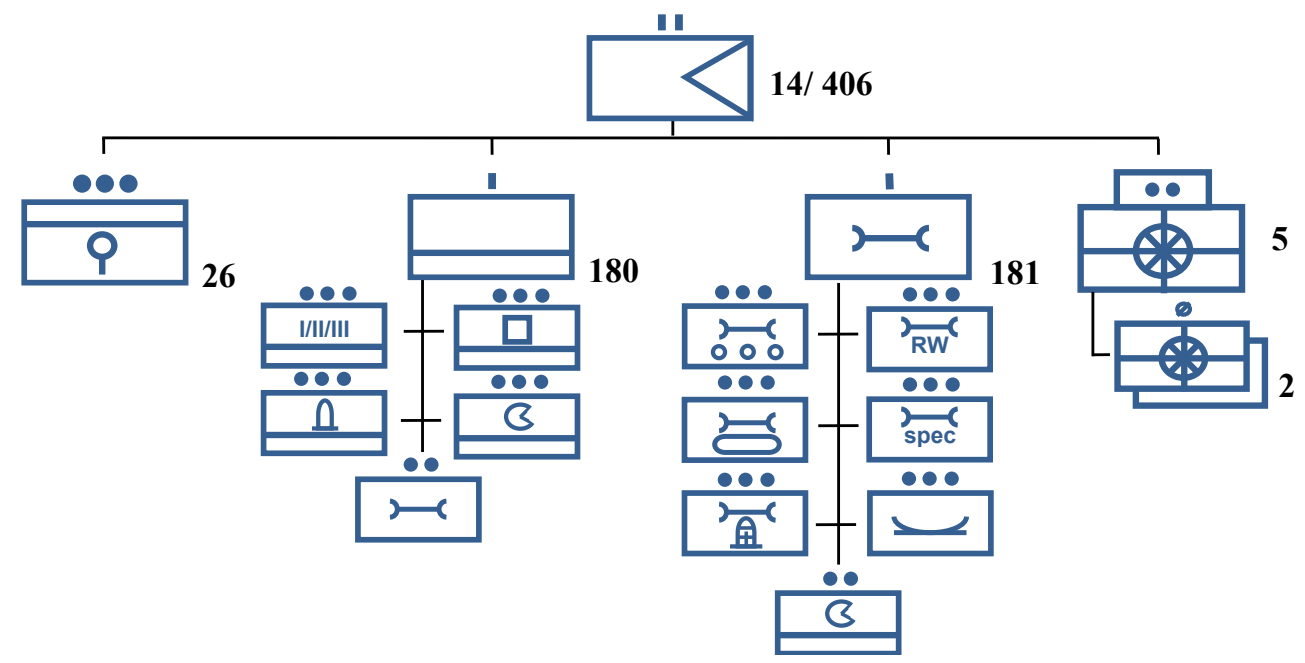

Source: Poradnik logistyczny do ćwiczeń i treningów sztabowych (Związek taktyczny, oddział, pododdział), M. Kaźmierczak (editor), ASzWoj, Warszawa 2016, p. 68.

Figure 3. The structure of logistic battalion of motorised/mechanised brigade

Taking into consideration the typical structure, it should be noted that this is the basis for organising logistic points i.e. the brigade supply point (BdeSP) and the maintenance collection point (MCP). Furthermore, the supply company organise material teams and supply convoys carrying out deliveries of ammunitions and material in accordance with the approved plan of delivery. Moreover, the maintenance company organise the evacuation repairs group (ERG), the technical evacuation group (TEG), and technical reconnaissance patrol (TRP). When organising the logistic points at this level, special attention should be paid to the area of their development in terms of safety and capacity. The brigade supply point takes place on average (depending on terrain) over $5-7 \mathrm{~km}^{2}$ which forces the issue of adequate force protection. However, the lack of force protection cells in 
LOGBN compel other solutions to be sought to provide them adequate protection. There is a similar situation with the Maintenance Collection Point organised by the maintenance company. It is deployed in the field or with the use of technical civil or military infrastructure in an area from 0.5 to $1.5 \mathrm{~km}^{2}$. MCP should be put in suitable formation to provide two technological lines for wheeled and tracked vehicles. In this case, the validity of using an observation (reconnaissance) UAV with a long endurance and a combat UAV which can start in a time short enough to react to the danger that might occur should be considered.

It is much more difficult to choose the class of UAV appropriate to escort supply tasks. This is due to significant distances of deliveries, the number of vehicles in the convoy, fewer own troops in this area, the possibility of impacts of enemy sabotage and reconnaissance groups, or the occurrence of hostile national minorities in the case of border regions. In this case, UAVs with a long flight time, heavier, with appropriate imagery parameters, and armed with weapons allowing firing at detected hostile objects threatening the security of the supply chain and logistic points should be chosen.
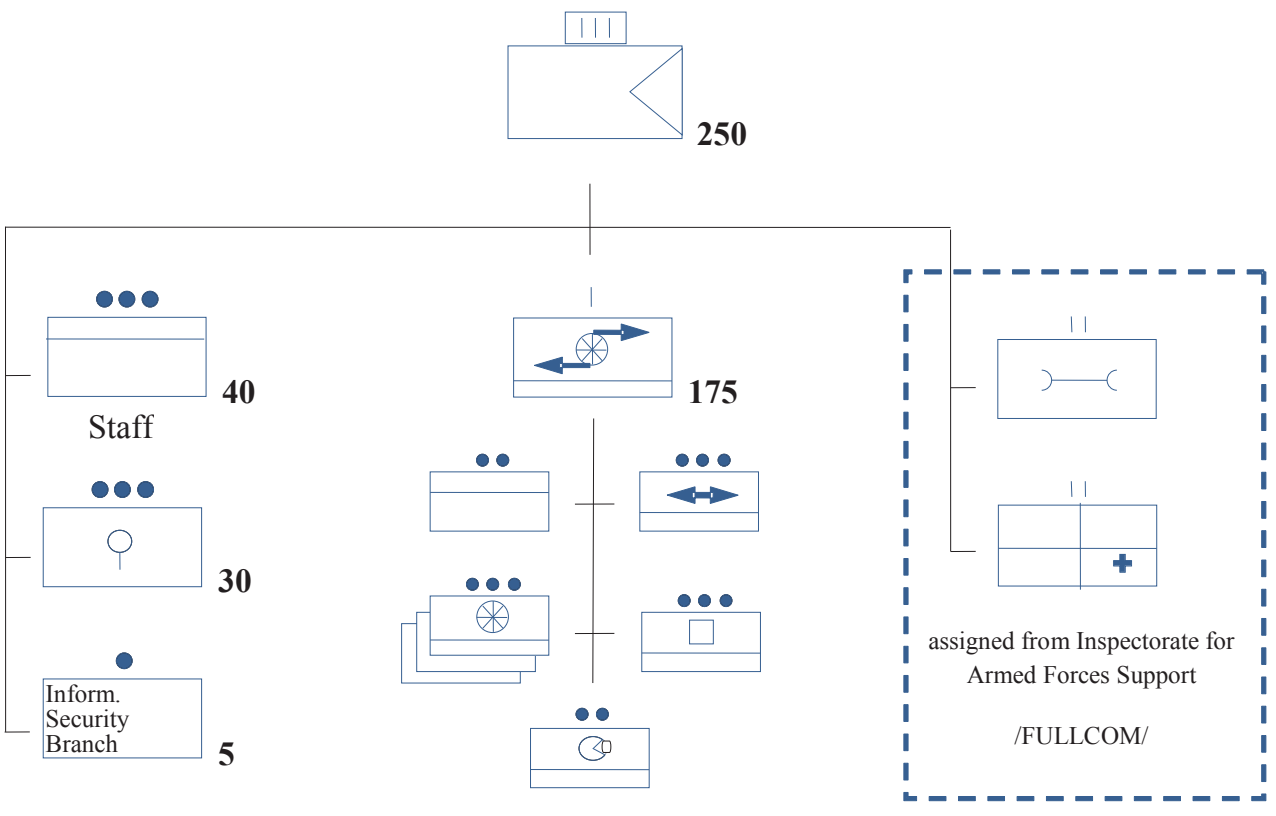

Source: Poradnik logistyczny do ćwiczeń i treningów sztabowych (Związek taktyczny, oddział, pododdziaf), M. Kaźmierczak (editor), ASzWoj, Warszawa 2016, p. 68.

Figure 4. The structure of divisional logistic support group 
The highest level of logistic support at the tactical level is currently secured by divisional logistic support group (DLSG). The organisational structure of DLSG is shown in Figure 4.

The group consists of: headquarters, delivery company (DELCOY), command platoon, force protection and traffic control platoon, Information Security Branch; along with assigned for wartime from the Inspectorate for Armed Forces Support: the maintenance battalion (MAINTBN) and the medical reinforcement battalion (MEDREINBN) and, depending on needs arising from the aims and scale of operations, other forces and means ${ }^{8}$.

The delivery company organises the divisional reloading point (DRP) which includes?:

- divisional food store;

- divisional POL store;

- divisional ammunition store;

- divisional engineering material store;

- divisional wear store;

- divisional store of technical materials and spare parts;

- service area;

- handling areas;

- unload waiting areas;

- columns forming area;

- parking area;

- DLSG commander command post;

- guard posts.

Developed DRP occupies up to $15 \mathrm{~km}^{2}$ which determines the selection of the appropriate UAV and their quantity.

The appointment of UAVs to protect supply convoys carried out on the basis of a delivery company may cause slightly more problems. This company is the executive DLSG, carrying out tasks of material support, transport of supplies, and developing

8 Poradnik logistyczny do ćwiczeń i treningów sztabowych (Zwiąek taktyczny, oddziat, pododdziat), praca zbiorowa pod red. M. Kaźmierczak, ASzWoj, Warszawa 2016, p. 109.

9 Ibidem. 
DRP. The DELCOY main tasks include: organisation and logistic support of transport and areas for reloading and unloading materials; distribution of supplies to the various means of transport; registry of properties and constant knowledge about manning resources and the efficiency of transportation / handling equipment; storage and protection of supplies; transport and short-term storage of materials; organisation of refuelling points; segregation of equipment and packaging classified for evacuation.

The main determinants influencing the selection of UAVs in this case are:

- the size of a subunit (convoy) supply;

- the structure of supplies;

- the length of the supply chain;

- terrain and weather conditions;

- season and time of day;

- the nature of activities and the combat environment;

- air attack threat;

- activity of enemy sabotage-reconnaissance groups in the depths of own troops.

Referring to the use of UAVs to protect an organised maintenance collection point by a maintenance battalion, one should take into account the dislocation of each point and the size of the area of development which is about 3 to $4 \mathrm{~km}^{2}$. It should also be remembered that MAINTBN organises the logistic elements, such as: evacuation repairs group (ERG), technical evacuation group (TEG), and technical reconnaissance patrol (TRP). All of them carry out the tasks of technical support in depths of their own troop formation.

\section{The inquiry research results of the application of unmanned aerial vehicles for the formation of a secure military supply chain}

This research has been carried out on a representative group of War Studies University students from the following studies and courses: Postgraduate Operational-Tactical Studies, Higher Operational-Strategical Course, Higher Operational-Logistic Course, and some short-term courses. 


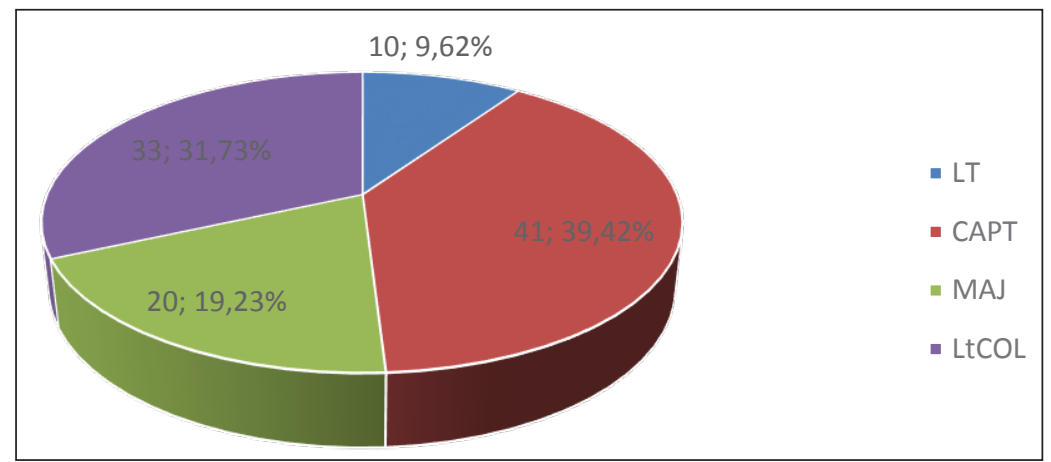

Source: the author's own research.

\section{Chart 1. The respondents' military rank characteristics}

In order to collect the impartial opinions of the broad respondents' group, an anonymous survey ${ }^{10}$ among junior and senior officers has been carried out. These officers originating from different military units and offices were studying at War Studies University at the time of the survey. The author attempted to question officers who dealt with the research subject during their hitherto service. They had different military specialties. The research sample included 122 people. 104 questionnaires were verified and classified (10 filled in by lieutenants, 41 by captains, 20 by majors, and 33 by lieutenant colonels). 18 remaining questionnaires were not significant sources of information - the respondents did not have sufficient knowledge or did not answer the questions for other reasons. Some questionnaires were also not taken into account because they were filled in partially or given answers were mutually exclusive.

Charts 1, 2, and 3 show that the respondents group consisted of both junior and senior officers, with different ranks, different specialties, from various environments, and with different experience. The majority served from 21 to 30 years (53 respondents). The second numerous group consisted of those who served from 11 to 20 years (42 officers). There were only 7 respondents with less than 10 ten years of experience. In the group were two respondents with the longest professional experience. The data analysed above shows that the majority of respondents was experienced, with 21 years or more in the service.

10 The questionnaire - see Annex 1. 


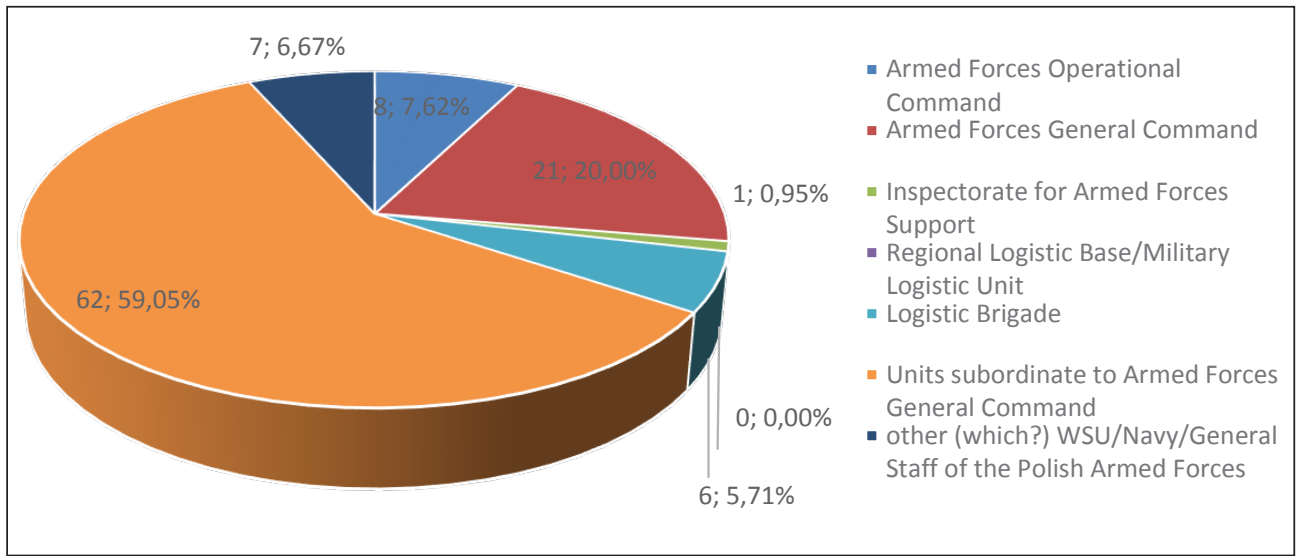

Source: the author's own research.

\section{Chart 2. The respondents' job location characteristics}

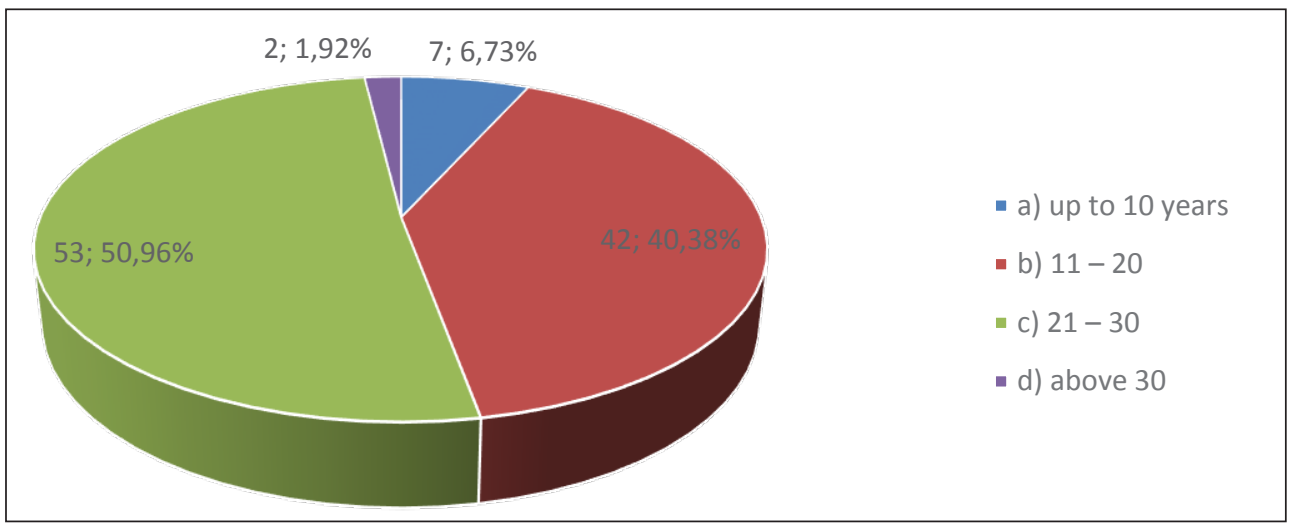

a) period of service

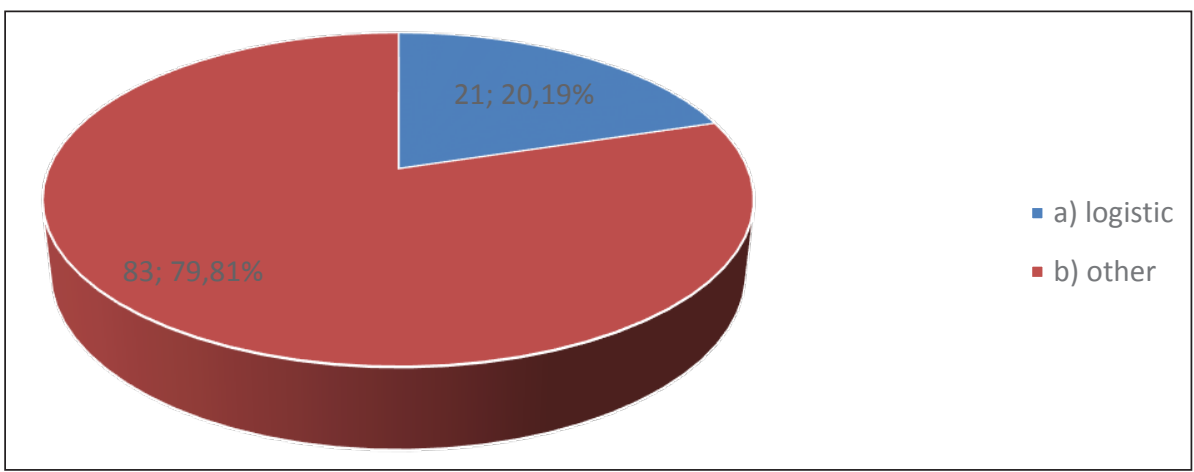

\section{b) specialty}

Source: the author's own research.

Chart 3. The respondents' period of service (a) and specialty (b) characteristics 
The logistics officers were a minority of respondents (20-21\%). The majority was of other specialties (80-83\%).

The first question concerned the respondent's knowledge about the possibilities of UAV applications. Chart 4 shows that more than $98 \%$ of respondents declared such knowledge (51.92\% - yes, $46.15 \%$ - rather yes). The complete lack of such knowledge was declared only by less than $2 \%$ (negligible minority). Such a result allows further analysis.

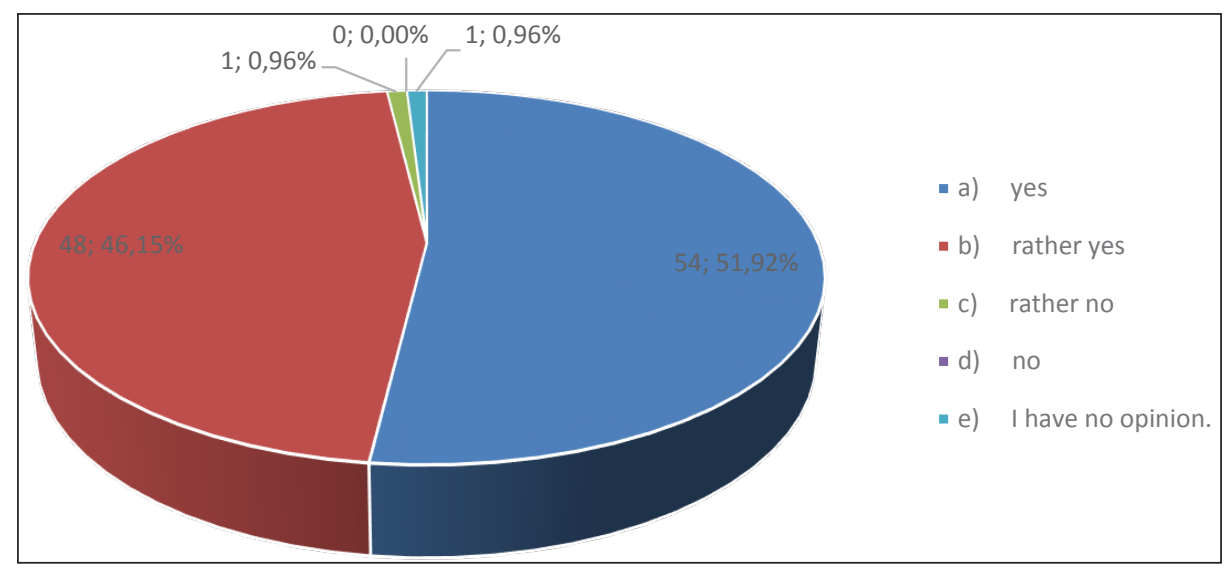

Source: the author's own research.

Chart 4. Are you familiar with the possibilities of application of unmanned aerial vehicles $(U A V)$ ?

The proportions of answers were similar for the subsequent question (chart 5.) which concerned the possibilities of UAV application for the force protection of tactical level logistic units, logistic points and elements. 95.5\% of respondents consider such application possible while only $4.81 \%$ gave a negative answer.

The next question in this group was about the possibilities of UAV application for the force protection of tactical level logistic units, logistic points and elements. The results depicted in chart 5 show that more than $95 \%$ of respondents $(57.69 \%$ - yes, $37.50 \%$ - rather yes) regard such UAV application possible. Only $4.81 \%$ declared that it is rather not possible to use UAVs to protect and defend the logistic units, logistic points and elements. It means that the great majority of respondents are open for the innovative technical solutions for supply chains security improvement and for the force protection of tactical level logistic units, logistic points and elements. 


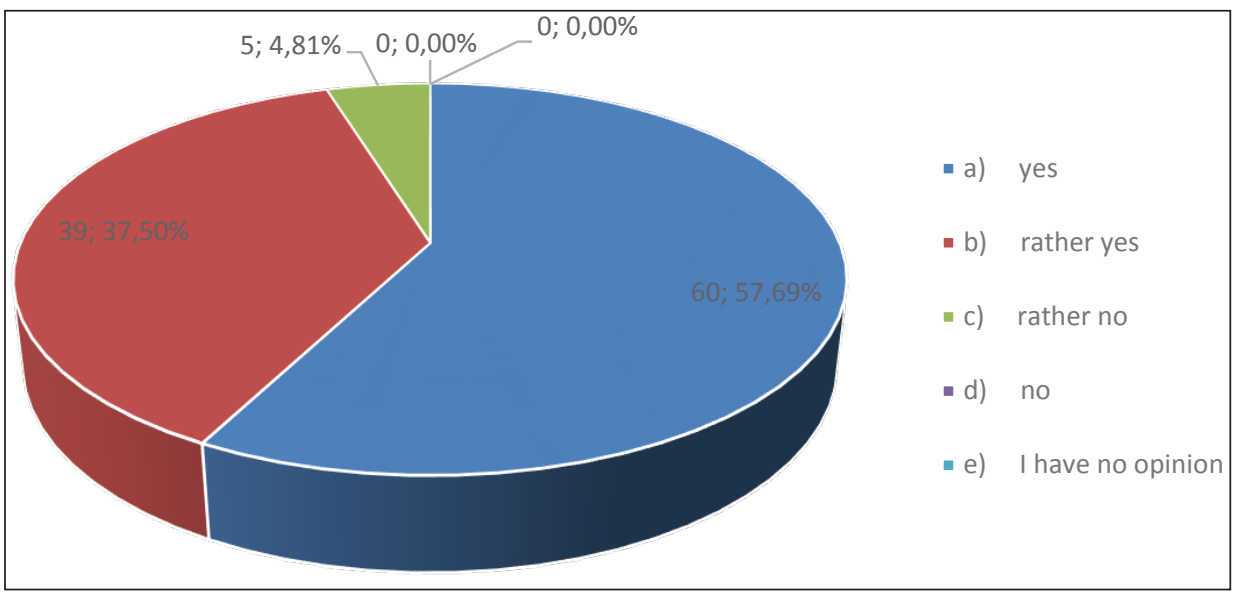

Source: the author's own research.

Chart 5. Do you think that it is possible to use UAVs for the force protection of tactical level logistic units, logistic points and elements?

Chart 6 shows the respondents' opinion about UAV classes which might be used for the force protection of tactical level logistic units, logistic points and elements. The answers were grouped according to: logistic company, logistic battalion, and divisional logistic support group.

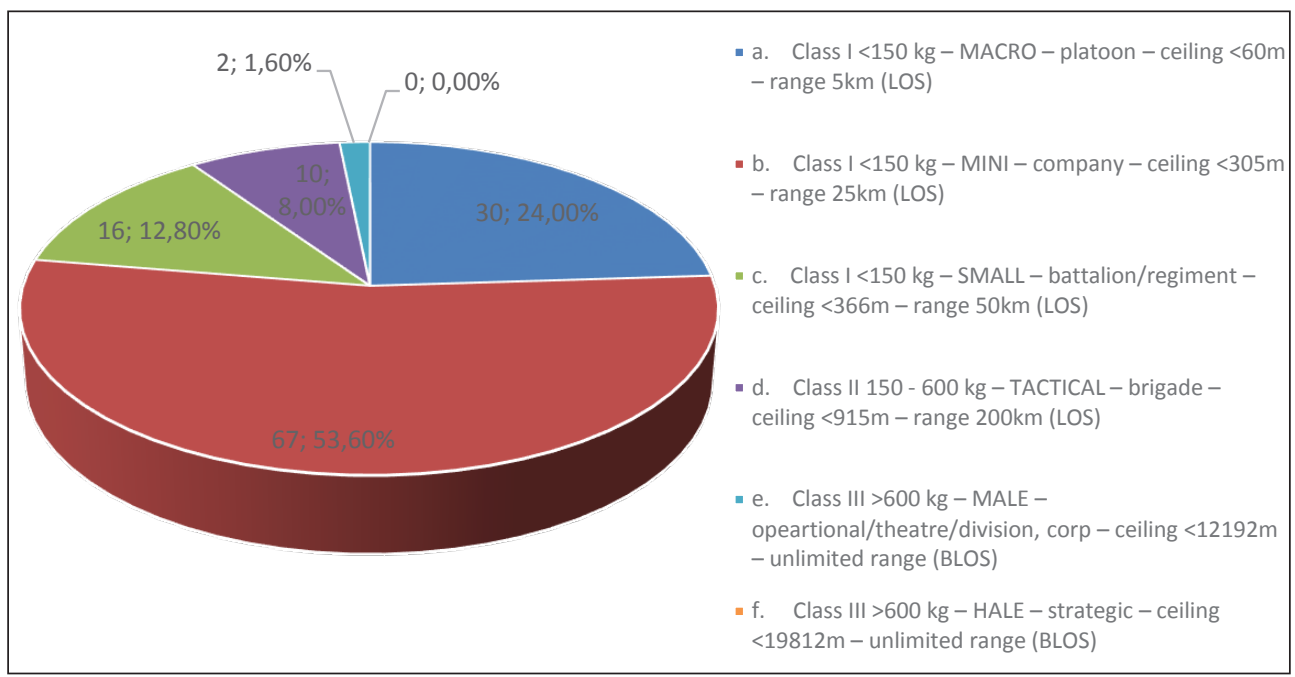

a) in the case of the logistic company (LOGCOY) 
When using UAVs for protection from the elements and supply chains organised by a logistic company, $53.60 \%$ of respondents declared that class I UAVs (MINI type, weighing up to $150 \mathrm{~kg}$, with an operational ceiling lower than $305 \mathrm{~m}$ and maximum range up to $50 \mathrm{~km}$ ) are applicable. $24.00 \%$ of respondents were for application of class I MACRO type (weighting up to $150 \mathrm{~kg}$ ) on platoon level. In this case, the UAV is designed for operations performed at an altitude of up to $60 \mathrm{~m}$ and up to $5 \mathrm{~km}$ of range. $12.80 \%$ of respondents considered class I SMALL type UAV applicable. This type of UAV is designed for battalion/regiment level where the ceiling is up to $366 \mathrm{~m}$ and the range does not exceed $50 \mathrm{~km}$. Only $8.00 \%$ of respondents consider class II UAVs (weighing between 150 and $600 \mathrm{~kg}$, with an operational ceiling of up to $915 \mathrm{~m}$ and range up to $200 \mathrm{~km}$ ) applicable in such case. This type is called TACTICAL and it is designed to be used at brigade level. 1.60\% of respondents answered that class III MALE type UAVs (ceiling up to $12192 \mathrm{~m}$, with unlimited range) are suitable in this case. None of respondents chose class III HALE type (designed for strategic level).

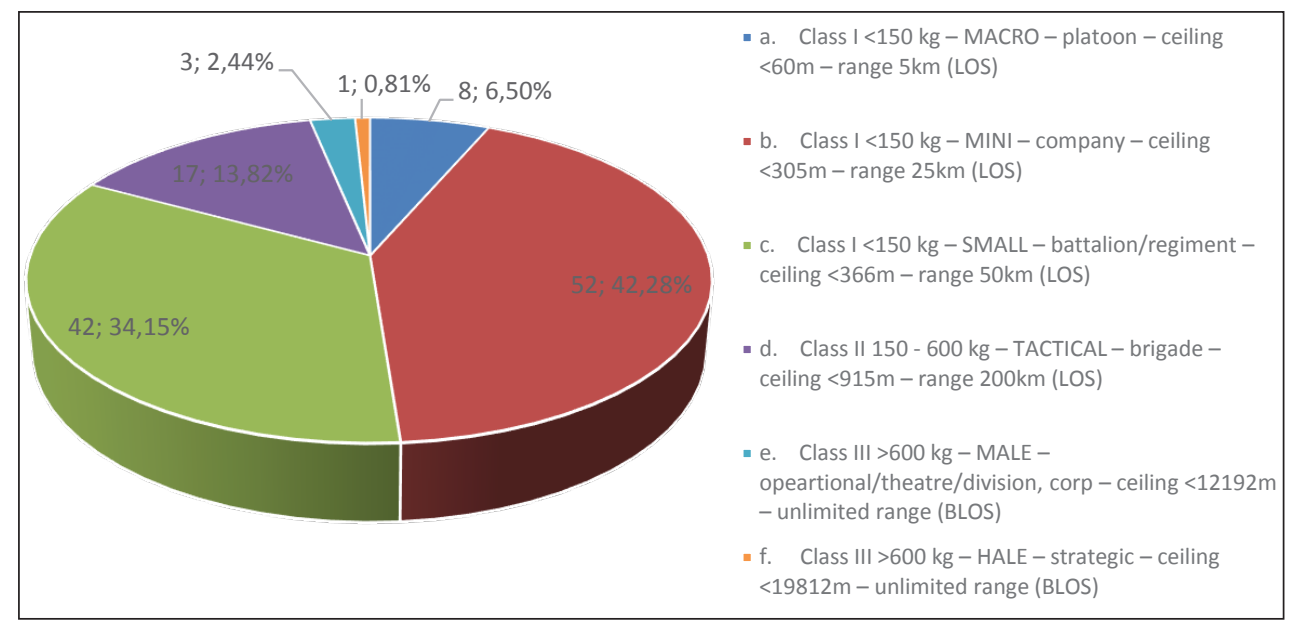

b) in the case of logistic battalion (LOGBATT)

42.28\% of respondents answered that class I MINI type UAVs (weighing up to $150 \mathrm{~kg}$, with an operational ceiling of lower than $305 \mathrm{~m}$ and maximum range up to $50 \mathrm{~km}$ ) should be applied for protection of the elements and supply chains organised by the logistic battalion. $34.15 \%$ of respondents considered class I SMALL type UAV applicable. This type of UAV is designed for battalion/regiment level where 
the ceiling is up to $366 \mathrm{~m}$ and the range does not exceed $50 \mathrm{~km}$. Only $13.82 \%$ of respondents consider class II TACTICAL type UAVs (weighing between 150 and $600 \mathrm{~kg}$, with an operational ceiling of up to $915 \mathrm{~m}$ and range up to $200 \mathrm{~km}$ ) applicable in such case. The use of other classes is considered reasonable by fewer than $10 \%$ of respondents (class I MICRO $-6.50 \%$, class III MALE $-2.44 \%$, class III HALE - 0.81\%).

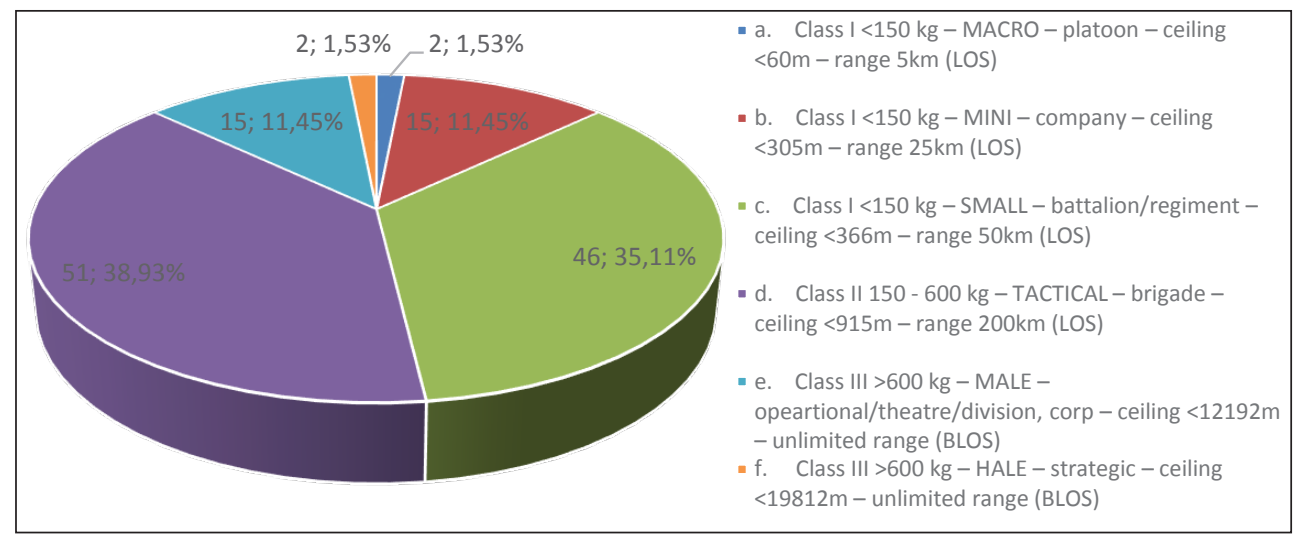

c) in the case of divisional logistic support group (DLSG)

Source: the author's own research.

Chart 6. Which sort of UAVs should be applied for the force protection of tactical level logistic units and elements?

Generally respondents regard only two UAV classes applicable in the case of DLSG. Class II TACTICAL type UAV (for brigade level) is considered the most proper. The parameters such as: weight up to $600 \mathrm{~kg}$, range up to $200 \mathrm{~km}$ and ceiling up to $915 \mathrm{~m}$; make it useful in this case. The class I SMALL type UAVs (designed for battalion/regiment level) are considered the second most applicable. The third place was shared between class I MINI type UAVs (for company level) and class III MALE type UAVs (for operational, theatre, and division level, weighing more than $600 \mathrm{~kg}$, with ceiling of up to $12192 \mathrm{~m}$ and unlimited range). 


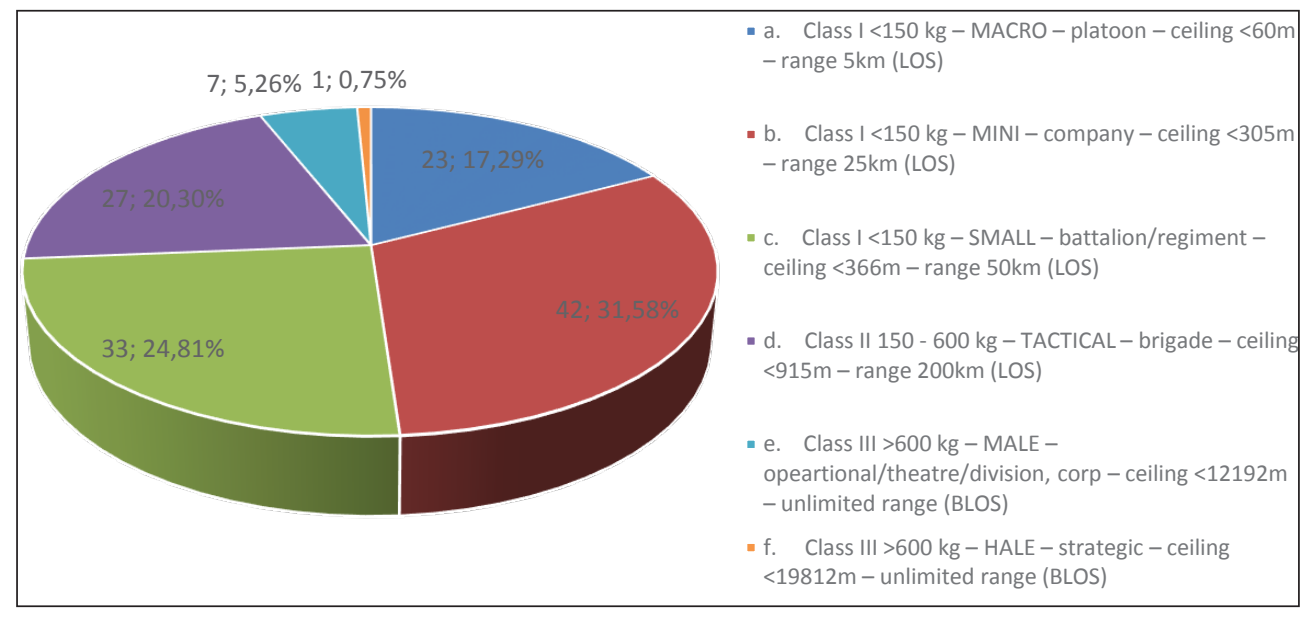

a) in the case of logistic company (LOGCOY)

Chart 7 shows the answers considering the use of UAVs for the force protection of tactical level logistic convoys. In the case of supply chains performed by a logistic company, $31.58 \%$ of respondents declared the application of class I MINI type UAV. This seems to be reasonable because of their ceiling of up to $305 \mathrm{~m}$ and operational range up to $25 \mathrm{~km}$. $24.81 \%$ of respondents stated that in the case of battalion dynamic operations in depth class, I SMALL type UAVs should be used because of their range (up to $50 \mathrm{~km}$ ) and their ceiling (up to $366 \mathrm{~m}$ ).

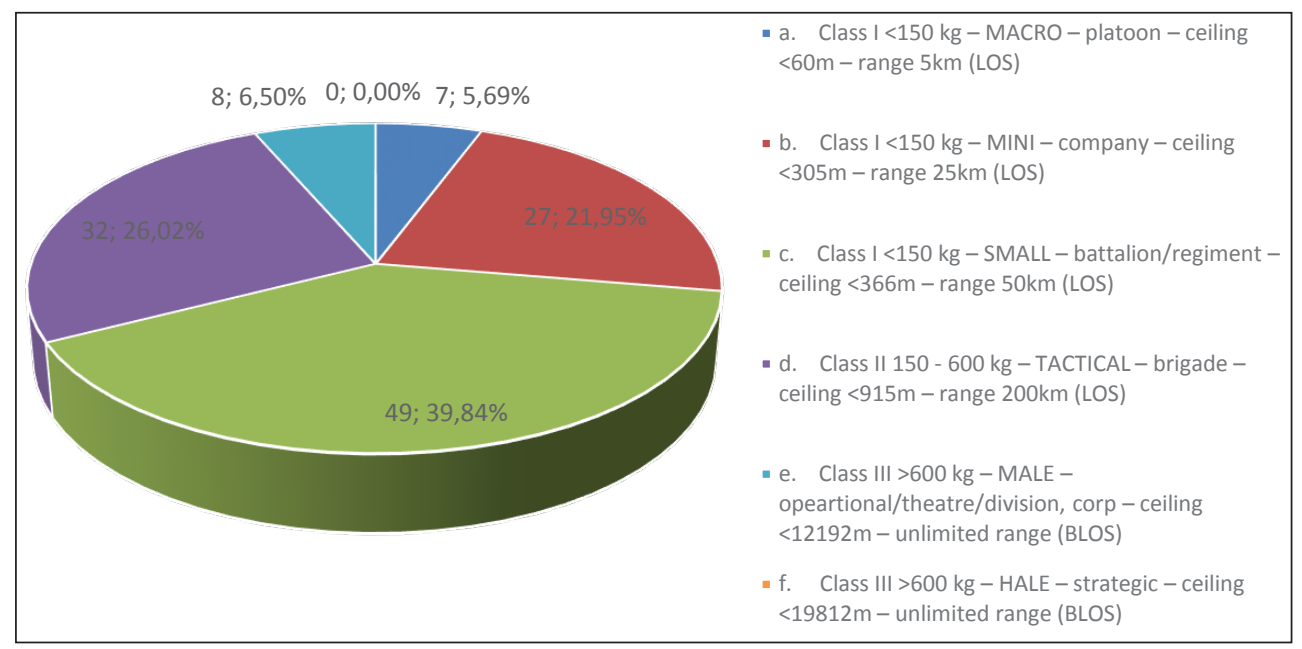

b) in the case of logistic battalion (LOGBATT) 


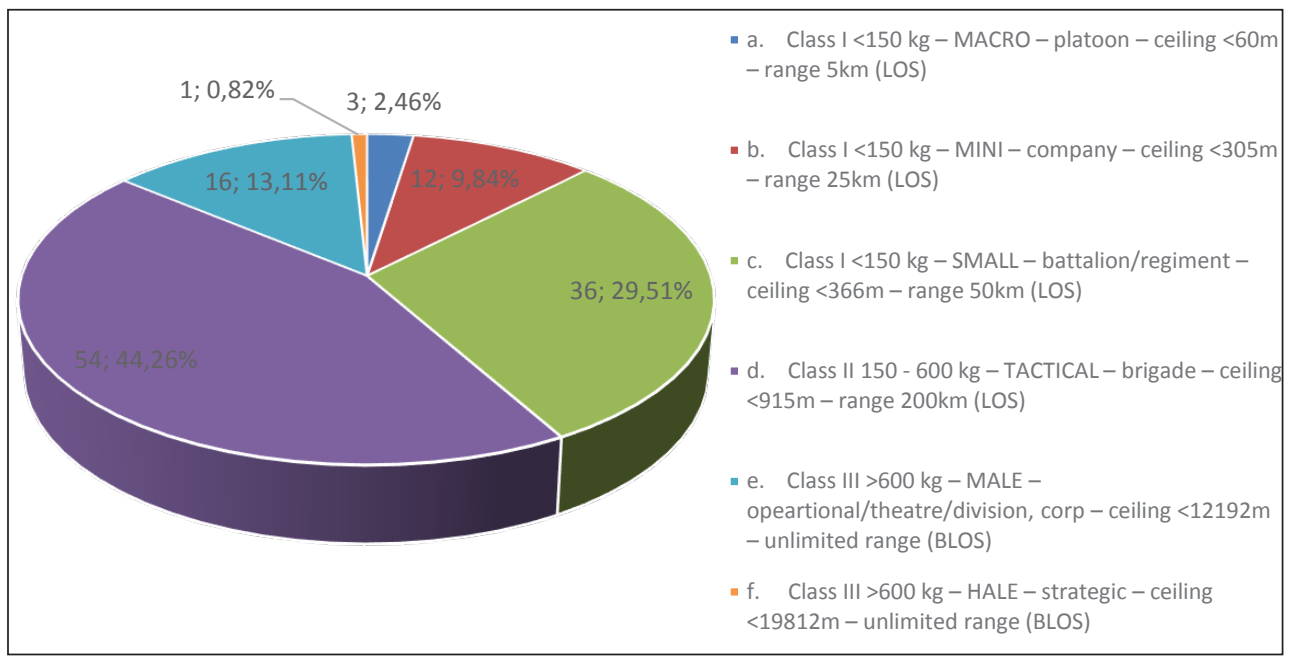

c) in the case of divisional logistic support group (DLSG)

Source: the author's own research.

Chart 7. Which sort of UAVs should be applied for the force protection of tactical level logistic convoys?

44.26\% of respondents answered that class II TACTICAL type UAVs should be applied for protection of the supply chains organised by the logistic battalion. This class of UAVs have a wide range (up to $200 \mathrm{~km}$ ) and ceiling of up to 915 $\mathrm{m}$. These parameters allow the operator to perform very freely in the depth of a brigade battle line where the supply convoys or maintenance elements are organised. Class II TACTICAL type UAVs seem to be suitable in this case for $26.02 \%$. Only $21.95 \%$ of respondents would use class I MINI type UAV at this level. Whereas other classes are considered optimal for this level by slightly more than $12 \%$ of respondents (MALE - 6.50\% and MACRO - 5.69\%). This is due to the designation and the range of these UAV classes.

Chart 8 shows that the respondents' choices are distributed almost evenly. $28.85 \%$ of respondents deems that the UAVs might be used for: reconnaissance and terrain observation, and direct fire support of units organising supply chains and logistic points. The second chosen task sets (26.92\%) were: reconnaissance and terrain observation along with operational support at tactical level, namely battalion or brigade levels, where the UAV's operation lasts up to 24 hours. $25 \%$ of respondents consider the reconnaissance and observation tasks performed using UAVs 
important for the force protection of logistic units and logistic points. Whereas 19.23\% of respondents think that UAVs should be engaged in reconnaissance, terrain observation, and operation support on tactical level, namely on squad, platoon or company levels. Flight duration for the UAVs performing such tasks is up to 6 hours. From the chart analysis, the conclusion might be drawn that just over $28 \%$ of respondents endorse the use of UAVs capable of performing reconnaissance, terrain observation, and logistic units and logistic points direct fire support. This is due to the UAVs' capabilities of direct fire on detected objects which threaten the logistic units, supply chains organised by them and established logistic points.

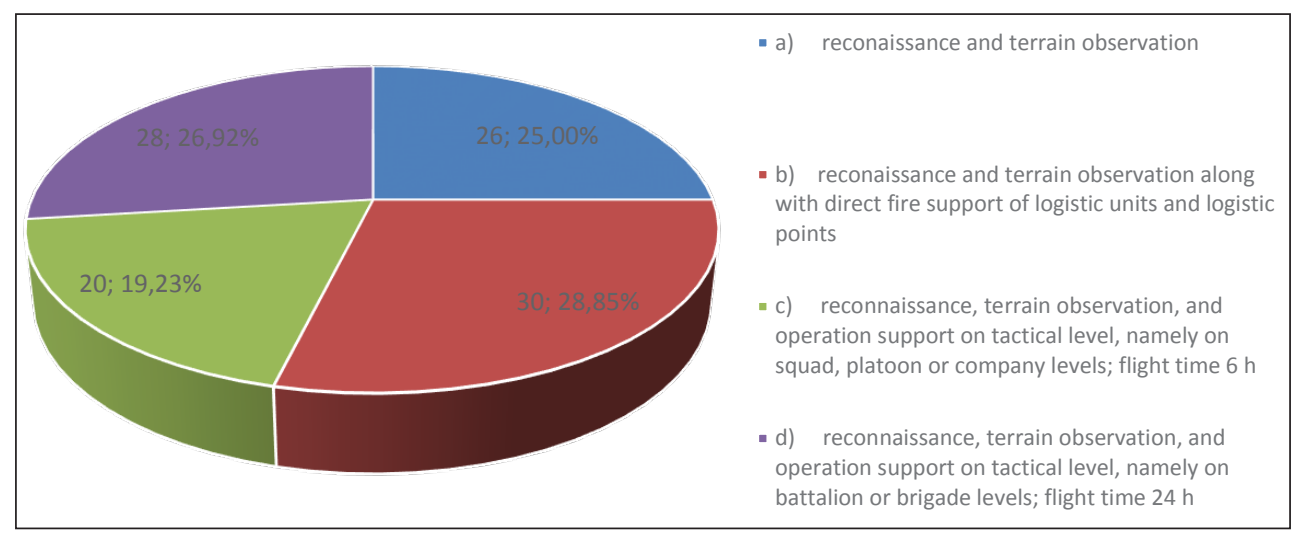

Source: the author's own research.

\section{Chart 8. What kind of tasks might UAVs be used for?}

There were eight factors distinguished in question from chart no. 9. These factors determined the proper selection of UAV type, their number, and the manner of their use for the force protection of logistic points. The respondents were to arrange them from first to eighth, where the first was the most important factor and the eighth the less important. The result showed that the most important factor for the respondents was the size of assembly area (8.16\%) and the second most important - the type of logistic points $(8.82 \%)$. The third was threat level (9.38\%) and, not much less important, logistic points' position in the battle line (11.37\%). The subsequent factors were (in order of importance): terrain (13.43\%), weather (15.47\%), season of the year (16.51\%), and time of day $(16.85 \%)$. 


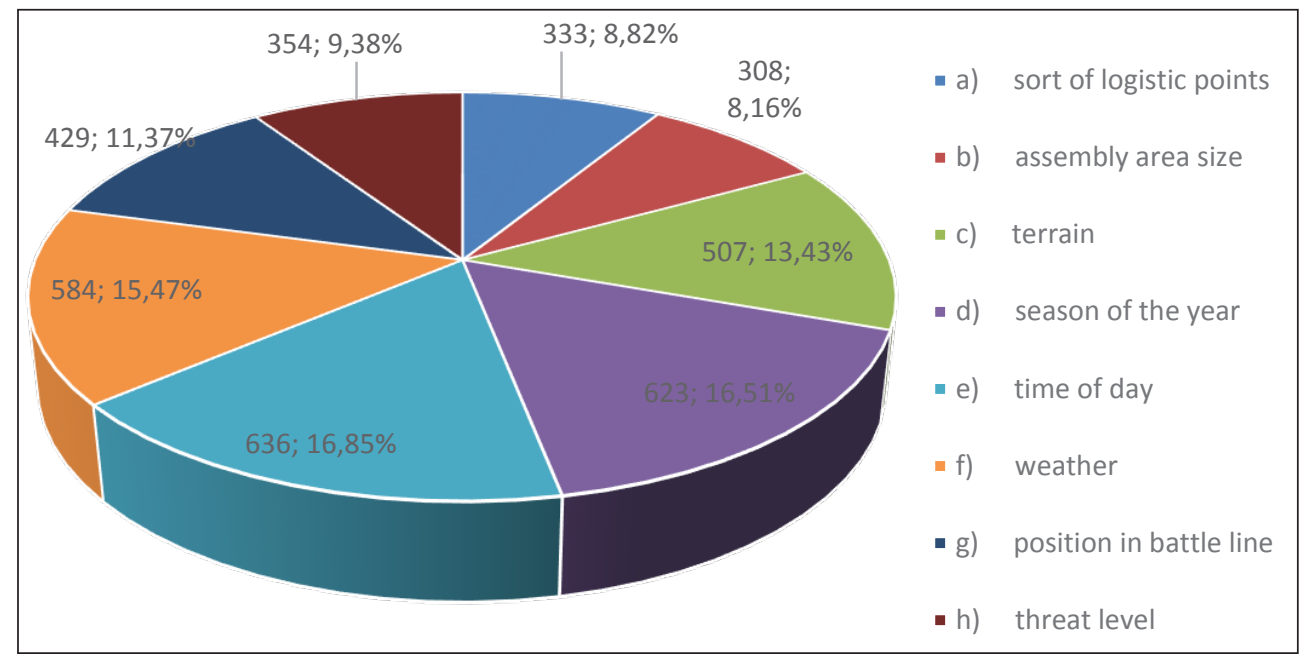

Source: the author's own research.

Chart 9. What should determine the sort, the number and the manner in which UAVS are used for the force protection of logistic points?

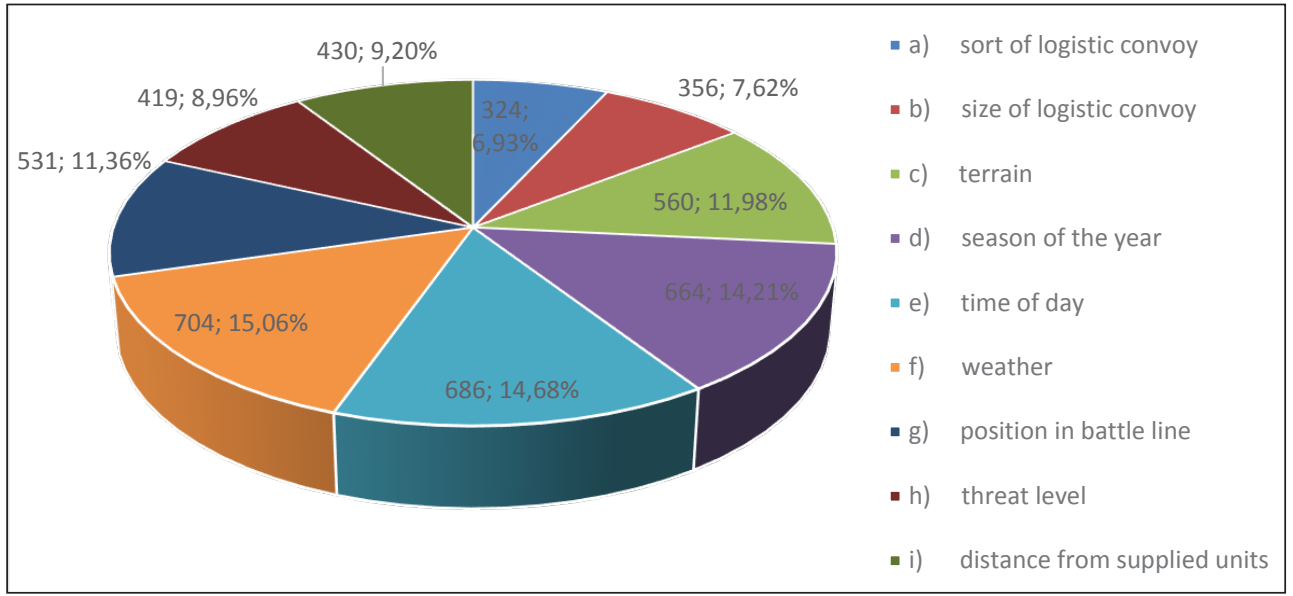

Source: the author's own research.

Chart 10. What should determine the sort, the number and the manner UAVs are used for the force protection of logistic convoys?

Chart 10 shows the respondents' opinion about the hierarchy of factors determining the UAV sort selection, their number, and the manner of using them for the force protection of logistic convoys. The methodology was similar to that from the previous question. The respondents chose the type of convoy (6.93\%) as the most important factor. The second was its size (7.62\%), the third - threat level (8.96\%), 
and the fourth - the distance from supplied units (9.20\%). The subsequent factors were (in order of importance): position in battle line (11.36\%), terrain (11.98\%), season of the year (14.21\%), time of day (14.68\%), and weather (15.06\%).

Charts nos 9. and 10. show that the most important determinants of choosing the types of UAVs, their number and methods of use are: the type of logistic points/ convoys, the size of assembly area/convoy, threat level, and the location in battle line or distance from supplied units. These determinants seem to be logical and their influence on UAVs application rational.

The next problem to be solved by respondents was the location of the UAV control centre (chart 11.). This problem was considered according to three command and control levels: logistic company, logistic battalion, and divisional logistic support group. In the case of logistic company, $57.69 \%$ of respondents stated that the logistic company command post is the optimal location for the UAV control centre. The battalion command post for its location was chosen by $39.42 \%$ of them. Whereas only $2.88 \%$ regarded thee brigade/regiment command post as the best option for the UAV control centre location. This research shows clearly that such centre should be located on the level of this unit which is protected and defended by the UAV.

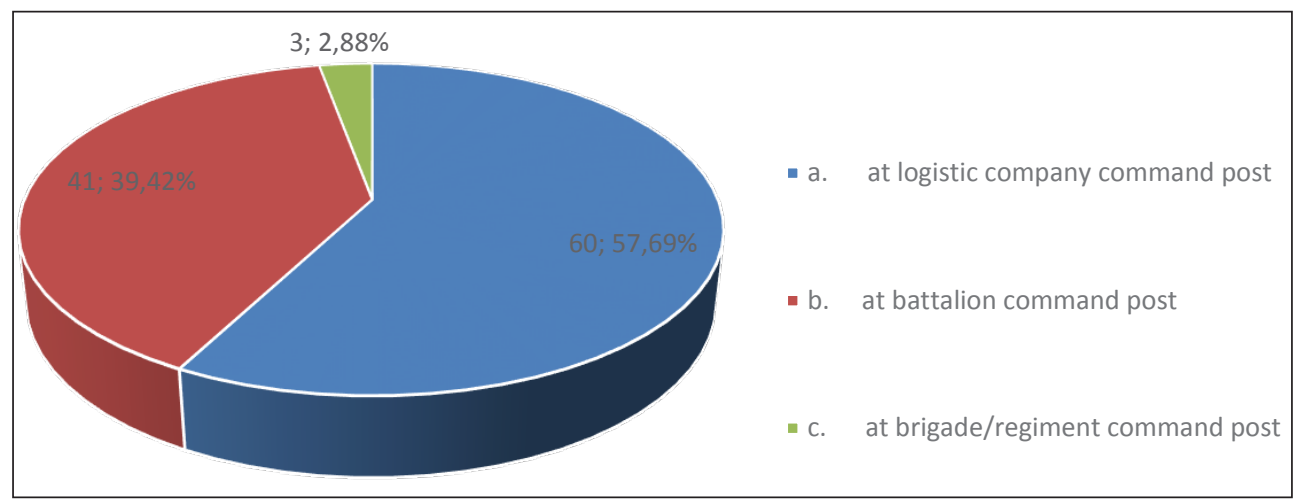

a) in the case of logistic company (LOGCOY) 


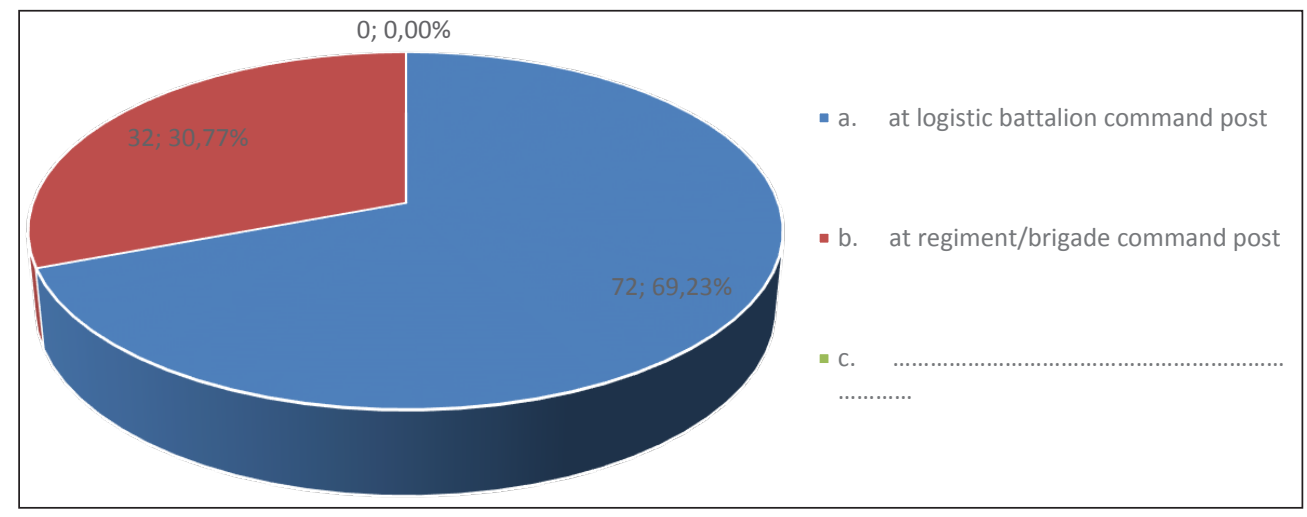

b) in the case of logistic battalion (LOGBATT)

Source: the author's own research.

In the case of logistic battalion, respondents chose the logistic battalion command post as the best location for the UAV operator (69.23\%). Only 30.77\% of them deem that such operator should work at a regiment/brigade command post. Regarding divisional logistic support group, $63.46 \%$ of respondents consider the divisional logistic support group command post the best place for the UAV control centre. While 36.54\% state that such centre should be located at the division command post.

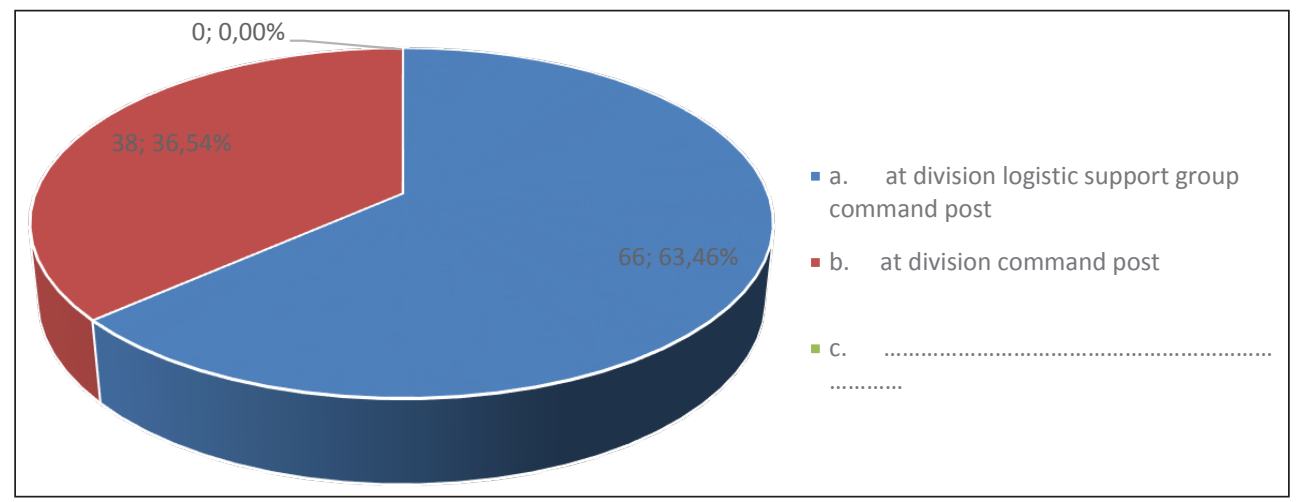

c) in the case of divisional logistic support group (DLSG)

Source: the author's own research.

Chart 11. What is the optimal location for the UAV control centre? 
The analysis of charts $11 \mathrm{a}, \mathrm{b}$, and c shows that the best location for the UAV control centre on each command and control level is the command post of the unit which profits from UAV usage. This is due to the fact that the commander of the adequate logistic unit will have the best knowledge about when, where, which sort of, and what number of UAVs should be used for the force protection of logistic units organising convoys, logistic elements, and logistic points.

\section{Summary}

The UAVs application for the force protection of logistic supply chains and logistic points established on each command and control levels is one of the methods of ensuring their security. This solution meets the requirements of tactical level logistics which does not have adequate force protection means. The problem is to properly identify the factors determining the choice of UAV's suitable class. From the analysis of UAV applications and inquiry results, the conclusion might be drawn that it is reasonable to use the unmanned aerial vehicles on tactical level for the force protection of logistic points and for formation of secure supply chains. The research results show that UAVs should be used for reconnaissance and terrain observation along with direct fire support for logistic units organising supply chains and logistic points. One of the results of the analysis is the conclusion that the most important determinants of UAV type selection, their number and the way they are used are: the sort of logistic point/logistic convoy, the size of assembly area/convoy, threat level, and the logistic point location in a battle line/ the distance from supplied units. According to command and control level, the aerial platforms of intelligence subsystem and armed forces protection subsystem should be used, so they can play the guard role. The research showed that small or medium-sized systems operating at low altitudes fulfil these requirements. While the long supply routes impose the necessity of using the type of UAV which can fly for a long time. Additionally, the delivery, loading, unloading and returning time should be taken into account. Regarding the UAV control centre, the best location is the command post of the unit which benefits from using unmanned aerial vehicles. 


\section{References}

Aktualny stan rozwoju bezzałogowych systemów autonomicznych w SZ RP, CDiSzSZ, Bydgoszcz 2015.

Autonomy Levels for Unmanned Systems (ALFUS) Framework Volume I: Terminology Version 1.1 by the Federal Agencies Ad Hoc Autonomy Levels for Unmanned Systems Working Group Participants, Edited by: Hui-Min Huang National Institute of Standards and Technology, September 2004

Cwojdziński L., Klasyfikacja oraz zasady eksploatacji bezzałogowych platform latających, motoszybowce.pl, (10.02.2017 r.).

Doktryna Logistyczna Sit Zbrojnych Rzeczypospolitej Polskiej D-4(B), MON, CDiSzSZ, Szkol. 888/2014, Warszawa 2014.

Doktryna logistyczna Wojsk Lądowych DD/4.2, DWLąd. 33/2007, Warszawa 2007.

Koncepcja bezzałogowych systemów autonomicznych w Siłach Zbrojnych RP, CDiSzSZ, Bydgoszcz 2016.

Poradnik logistyczny do ćwiczeń i treningów sztabowych (Związek taktyczny, oddziat, pododdziat), M. Kaźmierczak (editor), ASzWoj, Warszawa 2016.

Sajduk B., Problem walki na odległość w perspektywie historycznej, społecznej i etycznej, [w:] Systemy dronów bojowych. Analiza problemów i odpowiedzi społeczeństwa obywatelskiego, K. Kowalczewska (editor), J. Kowalewski, Scholar, Warszawa 2015.

Sprawozdanie końcowe z analizy nt. „Aktualny stan rozwoju bezzałogowych systemów autonomicznych w SZ RP”, Bydgoszcz 2015. 